\title{
The Black Military Experience
}

\section{Sources}

\begin{tabular}{||c||c|}
\hline \hline D 1.2: AF 8 & African Americans and World War II \\
\hline \hline D 1.2: B 56/991 & Black Americans in defense of our nation \\
\hline \hline D 1.2: C 88/3 & Invisible Cryptologists (printed from web) \\
\hline \hline D 1.2: SO 4/3 & Fort Myer Buffalo Soldiers \\
\hline \hline D 101.60/2: S 65x & Soldiers and sociology \\
\hline \hline D 101.60/3: R 33x & Race relations research in the US Army in the 1970s \\
\hline \hline D 103.438: 70-1-69 & Nothing but praise \\
\hline \hline D 110.2: B 86 & Buffalo soldiers at Fort Leavenworth \\
\hline \hline D 114.2: B 56 & SBlack soldier, white army \\
\hline \hline D 114.17: N 31 & Employment of negro troops \\
\hline \hline D 114.19: S W7 & Freedom by the sword \\
\hline \hline D 214.13: B 56 & Blacks in the Marine Corps \\
\hline \hline D 214.14/4: AF 8 & The right to fight: African-American Marines in WWII \\
\hline \hline D 301.2: B 56 & Blacks in the Army Air Forces \\
\hline \hline D 301.2: In 8/2/945-64 & Air force integrates, 1945-1964 \\
\hline
\end{tabular}

\section{Government Web Sites}

\begin{tabular}{|c|c|}
\hline Pictures of African Americans During World War II \\
\hline \hline Sergeant William Carney's Medal of Honor, 1863 \\
\hline \hline William Cathay--A One-of-a-Kind Buffalo Soldier \\
\hline \hline The "Buffalo Soldiers" on the Western Frontier \\
\hline
\end{tabular}

